\title{
SPEECH ACTS ANALYSIS OF PRE-SERVICE TEACHERS AND STUDENTS AT SMK NEGERI 1 SINGARAJA
}

\author{
Kadek Dhea Paramitha Amara Putri ${ }^{1}$ I Nyoman Adi Jaya Putra ${ }^{2}$, \\ Dewa Putu Ramendra ${ }^{3}$ \\ 1,2,3) Universitas Pendidikan Ganesha \\ kadekdheaparamithaamaraputri13@undiksha.ac.id 1
}

\begin{abstract}
This research aims to analyze the kind of speech act used by pre-service teachers and students of SMK Negeri 1 Singaraja in WhatsApp as learning media. Investigate the most dominant speech act used by pre-service teachers and students, and analyze the kind of instructional function used by the pre-service teachers. The data were analyzed using descriptive qualitative. The subject of this research is the pre-service teacher and students in SMK Negeri 1 Singaraja. The data were collected through observation and interview. The data from the observation was collected using an observation sheet which developed from Searle's (1969) theory of speech act and Johnson's (1997) theory of instructional function. The interview has been done semi-structured using an interview guide. The result shows that the pre-service teacher use four speech act in the learning activity; representative, directive, commissive, and expressive. The pre-service teacher uses directive speech to act dominantly to make the students active in the learning process. Meanwhile, the students use four speech act, including representative, directive, commissive, and expressive. The students use representative in dominant to be active and getting feedback in the learning activity. The kinds of the instructional function used by the pre-service teacher are control, organize, and motivational. It was found that the directive speech act functioned as control. Commissive functioned as organize. And expressive as motivational function.
\end{abstract}

Keywords: speech act, instructional function, pre-service teacher, student

\section{Introduction}

Communication is an essential thing in everyday life. According to Swandewi et al. (2018), communication is the process of exchange ideas, feeling, and information. People communicate using language, either written or spoken. The most important thing when people communicate is the topic of the conversation.

Sometimes, people talk using an implied meaning behind the utterances. In guessing the meaning behind the utterances, we must look at the situation or contexts when the utterance is spoken. Situation or contexts affected the meaning behind the utterance. Austin (1975), as cited in Baktir (2012), stated that speech is classified based on the function that is called speech act. According to Searle (1969), as cited in Swandewi et al. (2018) speech act is the central unit or main communication unit.

According to Searle (1969), speech act has five classifications: representative, directive, commissive, expressive, and declarative. Representative is a speech act which states what the speaker believes. Directive is a speech act which the speaker use to ask someone to do something (Sumedi \& Rovino, 2020; 123). Commissive is speech that use to commit future action (Sumedi \& Rovino, 2020; 123). Expressive is a speech act that 
expresses the speaker feels. Declarative is a speech act that changes the world or situation.

Speech act also can be found in written utterances. In communication, people nowadays also using electronic media. Some applications which have facilities call and message, especially in this covid-19 pandemic, where people have to work from home. People have to use electronic media to communicate with other people. Schools are also temporarily closed, so the learning process must be done from home.

In doing the teaching and learning process from home, the teachers use some application and electronic media to help them communicate with students. Some school use video conference meetings, so they can do the learning process synchronously. Moreover, other schools only use chatting applications because of the limitations of the facilities. One of the chatting applications that teachers use is WhatsApp. WhatsApp is one of the chatting applications that the teacher uses as a learning medium. WhatsApp has facilities that can help the teacher in learning processes, such as sharing videos, pictures, and documents. Although teaching in limited situations, teachers have to make a successful learning process to achieve the learning goals.

Language is the approach in education (Merdana et al., 2013; 2). Language is a tool for the teacher in delivering material in the learning process. According to Basra and Toyyibah (2017), the students sometimes misunderstand the teachers' explanation in teaching a foreign language. Based on the problem above, the researcher is interested in seeing whether teaching and learning using electronic media is effective.

Speech acts were the medium in the learning process. According to Merdana (2013), language in classroom interaction is related to the instructional function of speech act including control, organize, and motivational. So, the researcher would like to analyze the speech act and the instructional function in the teaching and learning process through electronic media or application. The application chosen is WhatsApp. WhatsApp is used by most teachers in teaching because it does not burden the students for the facilities. Video conference spends a lot of internet package, so the teachers chose to use WhatsApp, which not spend many internet packages.

This research uses pre-service teachers and students as the subject because research that uses pre-service teachers and students is still limited. Preservice teachers from Ganesha University of Education and students from SMK Negeri 1 Singaraja were chosen as the subject. Pre-service teachers were chosen because they are still a beginner who is doing practice teaching before becoming teachers. Students from SMK Negeri 1 Singaraja that chosen is from departement Perhotelan (hospitality). The students in that department have to prepare before they do an internship.

In conducting this research, some of the previous studies help the researcher in doing this research. Swastiana, Putra, and Suarnajaya (2020) writes the similar research. The subject of the research is the seventh-grade English teacher. The researchers found that the teacher use representative, directive, expressive, 
commissive, and declaration. Besides, the second research was conducted by Chakim and Dibdyaningsih (2019). The research is focused on teachers' speech acts in giving motivation to the students. The researchers found that the teacher use representative, directive, expressive, commissive, and declaration in giving motivation. And the most dominant used is directive. The third researchers are Andewi and Waziana (2019). The findings showed that the teacher use four speech acts, representative, expressive, directive, and commissive. The teacher dominantly used directive speech acts. The teacher's types and functions of directive speech acts are need statement, bald imperative, permission directive, and question directive.

Based on the problem and the previous research above, the teacher has an important role in the teaching and learning process. The teacher has a role in delivering material and achieving the learning goals. Speech act also has a role as a medium in communicating and interaction in the classroom. It makes the researcher interest to conducted research on speech acts used by the pre-service teacher and students in SMK Negeri 1 Singaraja.

\section{Method}

This research uses descriptive qualitative in collecting and analyzing the data. According to Hancock et al. (2009), qualitative research is conducted by developing social phenomena explanations. Descriptive qualitative research which describes the phenomena and the data (Swandewi et al., 2018; 4). Descriptive qualitative is used to describe the data of speech acts used by pre-service teachers and students and the instructional function of speech act used by pre-service teachers of SMK Negeri 1 Singaraja through Whatsapp group. Descriptive research is focused on describing phenomena (Goundar, 2012; 5). Data in descriptive qualitative were showed by description and result.

In conducting this research, two instruments were used to help the researcher analyse the data; an observation sheet and an interview guide. The observation sheet was create based on Searle's theory of speech acts and Johnson's theory of instructional function. Based on Searle's (1969), five kinds of speech act, including representative, directive, commissive, expressive, and declarative. According to Johnson (1997), there are three categories of instructional functions of speech acts; control, organize, and motivational. The second instrument is an interview guide which used as guidance in interviewing to get detailed information. In this research, the researcher uses semi-structured interview. According to Mathers et al. (2000), the interviewer and interviewee could discuss their topic in detail in a semi-structured interview.

In achieving credibility and validity of the finding, the researcher use investigator triangulation and data triangulation. Investigator triangulation is triangulation that involves evaluators in evaluating data (Guion, 2002; 2). In the investigator triangulation, the researcher has transcribed the data into the observation sheet, and then the data would be processed and evaluated by the investigators. Data triangulation is triangulation that involves a different source of data (Guion, 2002; 1). In data 
triangulation, the researcher got the first data from observation and the second data through interview.

\section{Finding and Disscusion}

In this research, the pre-service teachers and students' speech act were classified using Searle (1979) theory of speech act. According to Searle (1979), there are five kinds of speech act; representative, directive, commissive, expressive, and declarative. Therefore, in this research it was found four speech act used by the pre-service teacher and students of SMK Negeri 1 Singaraja through WhatsApp including representative, directive, commissive, and expressive. The instructional function of pre-service teachers' speech act was analyze using Johnson (1997) theory of instructional function. According to Johnson (1997), there are three kinds of instructional function; control, organize, and motivational.

\subsection{Kind of Speech Act Used by Pre- Service Teachers}

Based on the analysis, the researcher found four kinds of speech act used by the pre-service teacher; representative, directive, commissive, and expressive. From the data, there are 292 utterances produced by the pre-service teachers. In data, there are 46 utterances categorized as representative speech act. The percentage of the representative speech act is $15,7 \%$. The next is directive speech act with total 172 and percentage $59 \%$. Commissive speech act occurred with total 32 utterances and percentage $11 \%$. The last is expressive speech act with total 42 and percentage $14,3 \%$.

\subsubsection{Representative}

Representative is a speech act that said what the speaker believes (Yule, 1996; 53). Based on the data, representative occurred with total 46 speech act and percentage of $15,7 \%$. The example of representative spoken by pre-service teachers was:

"So, this is an example of invitation letter."

From the example above, the preservice teacher giving an example of an invitation letter to the students. Through this utterance, the pre-service teacher delivering information to the students. In the classroom, the representative speech act is mostly used to delivering material. Representatives have the function to deliver material and give information (Swandewi et al., 2018; 9).

\subsubsection{Directive}

Directive is a speech act in which the speaker asks the hearer to something (Yule, 1996; 54). In this research, it was found 172 utterances that categorized as directive and percentage of $59 \%$. The example of directive uttered by the preservice teacher was:

"Do you know what are the parts of an invitation letter?"

The pre-service teacher uttered this question to ask the students about the part of an invitation letter. The pre-service teacher uttered this sentence to check the students' understanding of the material. And the pre-service teacher wants the students to share their opinion. Thus, this utterance was categorized as directive because the pre-service teacher uttered the sentence to ask the students to give their opinion. Directive is a speech act used when the speaker wants to tell someone to 
do something (Yule, 1996 as cited in Chakim \& Dibdyaningsih, 2019; 226).

\subsubsection{Commissive}

Commissive speech act is a speech act that the speaker commits a future action (Yule, 1996; 54). Based on the result, the commisive speech act is presented with total of 32 utterances and percentage of $11 \%$. An example of the commissive speech act was below :

"I will continue to the next activity."

The pre-service teacher produced this utterance to tell the students what they will do next. Through this sentence, the pre-service teacher tells her plan to continue the activity. In the example above, there is the word "will", which tell the future action. Commissive is used to tell plan that is done by the teacher (Swandewi et al., 2018; 8).

\subsubsection{Expressive}

Expressive speech act is a speech act that tells about the speakers' feeling (Yule, 1996; 53). Based on the data, the total of expressive speech act is 42 and the percentage $14,3 \%$. An example of expressive speech act uttered by the preservice teacher was :

"Okay some of you have a good opinion about it."

From the sentence above, the preservice teacher gives compliment to the students. At that time, the pre-service teacher asks the students to give their opinion about the material given. Then, the-pre service teacher gives praise to them because they have a good opinion. Expressive speech act expresses the speaker felling such as; likes, refusal, pledges, etc. (Yule, 1996 as cited in Chakim \& Dibdyaningsih, 2019; 227).

\subsection{Kind of Speech Act Used by Students}

There are four kinds of speech act used by the students; representative, directive, commissive, and expressive. The students produce 348 utterances. Representative speech act with percentage $62,1 \%$ and total 216 utterances. And the next is directive speech act with percentage $26,7 \%$ and presented 93 of total utterances. The next is commissive with total 4 utterances and percentage of $1,1 \%$. The last is expressive speech act which presented 35 total utterances and percentage $10,1 \%$.

\subsubsection{Representative}

Based on the result, the students used representative speech act with total 216 utterances and percentage $62,1 \%$. The example of representative speech act uttered by the students was:

"Number 2 contains contacts for reservation and gmail."

The students mostly use representative speech act when giving their opinion or answering the pre-service teacher's questions. In the example above, pre-service teacher asks the students to give their opinion about the structure of the invitation letter. Then, the students try to answer by uttering the sentence above. Thus, the example above is categorized as representative because it uttered by students to give their opinion. According to Yule (1996), as cited in Basra \& Thoyyibah (2017), representatives represent what the speaker believes. 


\subsubsection{Directive}

Based on data, the students' directive speech act was 93 utterances and with percentage $26,7 \%$. An example of directive speech act that used by the students was: miss."

"Let's continue to the next activity,

From the example above, the students ask the pre-service teacher to continue the activity. Thus, the sentence above was directive because it used by the students to ask the pre-service teacher to do an act. The speaker uses directive speech act to tell someone to do something (Basra \& Thoyyibah, 2017; 76).

\subsubsection{Commissive}

The result of the commissive speech act uttered by the students was 4 utterances and a percentage of $1,1 \%$. The example of commissive speech act that used by the students was :

"I will check it."

The student uttered this sentence when the pre-service teacher asked her to check who is not present. Through this sentence, the student promised that she would check the attendant list. Thus, the sentence above was a commissive speech act. Commissive speech act is an offer and promise (Andewi \& Waziana, 2019; 32).

\subsubsection{Expressive}

Based on the finding, the students' expressive speech act was 35 and percentage $10,1 \%$. The example of an expressive speech act used by the students was: miss?"

"I am good, how about you

This sentence was uttered by the students when the pre-service teacher asks how the students are. The students answer by telling their feeling or condition. Thus, the sentence above categorized as expressive speech act because the sentence was uttered to tell the students' feeling. Expressive speech act shows what the speaker feels about something (Basra \& Thoyyibah, 2017; 76).

\subsection{The Most Dominant Speech Act Used by Pre-Service Teachers and Students}

The finding found that the preservice teacher using directive speech act in dominant with percentage $59 \%$ and total 172 utterances. Therefore, there are some reasons why the pre-service teacher use directive act dominantly in the learning activity. The reason is that the pre-service teacher learning approach used. The pre-service teacher used Direct instruction (DI) in the learning process, so the pre-service teacher must instruct the learning process. According to Ruutmann \& Kipper (2011), direct instruction is a teaching approach in which the teacher has to state the goal, give direct instruction, monitoring the outcomes, and use effective classroom management.

The second reason is that the preservice teacher wants the students to be active in the learning activity. The preservice teacher often asks the student to give their opinion and share their knowledge because the pre-service teacher wants them to participate in learning activities. Then, because the learning process is done via WhatsApp, the pre-service teacher wants to check whether the students understand the material. So, the pre-service teacher often give questions to the students to check their knowledge. 
Based on the result, the students use representative speech act dominantly with total 216 utterances and percentage $62,1 \%$. The students' reason using representative speech act dominantly is because the students want to active in the learning activities in order to get bonus score if they answer the pre-service teacher's question. It also influenced by the pre-service teacher's utterance in which the pre-service teacher is frequently giving question and instruction to the students. So, the students have to answer the question given.

\subsection{Instructional Function Used by Pre- Service Teachers}

There are three kind of instructional function of speech acts used by pre-service teacher including control, organize, and motivational. In this research it was found that directive fuctioned as control, commissive as organize function, and expressive which has motivational function.

\subsubsection{Control}

\section{Directive :}

\section{"Via link, please."}

Based on the sentence above, the pre-service teacher controls the student by giving a command. The pre-service teacher is giving command when asking for the link to the WhatsApp group class. By giving a command, the teacher could control the classroom activities (Swandewi et al., 2018; 9).

\subsubsection{Organize \\ Commissive :}

"Then if we have time, you will perform your dialogue with your partner via video call with me."
From the utterance above, the preservice teacher organizes the learning activity by telling the students what would they do next. Commissive speech act has function tell the future action. Commissive speech act has control and organize function in learning activities (Johnson, 1983 as cited in Sumedi \& Rovino, 2020; 128). In the learning process, the commissive speech act used to organize and tell the students about what activities they should do next (Sumedi \& Rovino, 2020; 128).

\subsubsection{Motivational}

\section{Expressive :}

"Amazing."

In the utterance above, the preservice teacher praising the students when the students were answering the question given. The pre-service teacher usually praises the students when they try to answer the question given to motivate them. The function of expressive speech act is to express someone's feeling, but it also has the main motivational function (Swandewi et al., 2018; 10). Expressive speech act has a motivational function because it used to motivate the students in the learning process (Johnson, 1983 as cited in Sumedi \& Rovino, 2020; 128).

\section{Conclusion}

Based on the finding and discussion, the researcher can conclude that:

There are four kinds of speech act used by pre-service teacher and students of SMK Negeri 1 Singaraja in WhatsApp as learning media. Pre-service teachers and students' kind of speech acts are representative, directive, commissive, and expressive. Total utterance produce by 
pre-service teachers are 46 utterances categorized as representative speech act with percentage $15,7 \%$. Directive speech act with total 172 and percentage 59\%. Commissive speech act with total 32 utterances and percentage $11 \%$. The last is expressive speech act occurred with total 42 and percentage $14,3 \%$. The speech act produces by the students are representative speech act with total 216 utterances and percentage 62,1\%. Directive speech act with percentage $26,7 \%$ and presented 93 of total utterances. Commissive, with which presented 4 utterances of the total utterances and percentage $1,1 \%$. The last is expressive speech act with total 35 utterances and percentage $10,1 \%$.

The pre-service teacher uses directive speech act dominantly from the four speech act produced by the preservice teacher. Pre-service teacher use directive dominantly in order to make the students active in the learning process. Meanwhile, the students dominantly use representative speech act. The reason is that the students' utterance is influenced by the pre-service teachers' utterance. The pre-service teacher was often giving question to the students. So, the students answering the question using a representative speech act. The other reason is that the students want to participate in the classroom to get a bonus score.

There also found the instructional function of speech act used by the preservice teacher in learning process. There are three instructional functions found, including control, organize, and motivational. Directive has functioned as control. Commissive as organize. And the last, expressive as a motivational function.

\section{References:}

Andewi, W., \& Waziana, W. (2019). An Analysis of Teacher's Speech Acts in Teaching and Learning Process. Teknosastik, 29-34.

Baktir, H. (2012). Speech Act Theory : Austin and Searle: Derrida's Response and Deleuze's Theory of Order-Word. Language, Literature, and Cultural Studies , 5 (2), 201-210.

Basra, M. S., \& Thoyyibah, L. (2017). A Speech Act Analysis of Teacher Talk in an EFL Classroom. International Journal of Education , 73-81.

Chakim, M. A., \& Dibdyaningsih. (2019). An Analysis of Teacher Speech Act In Giving Motivation for English Students. Journal of English Language Teaching and Islamic Integration, 218-229.

Goundar, S. (2012). Research Metodology and Research Method. Victoria University of Wellington

Guion, L. A. (2002). Triangulation: Establishing the Validity of Qualitative Studies. University of Florida Extention, 1-3.

Hancock, B., Ockleforf, E., \& Windridge, K. (2009). An Introduction to Qualitative Research. The National Institute for Health Research .

Johnson, K. (1997). An Introduction to Foreign Language Learning and Teaching. Beijing: Foreign Language Teaching and Research. 
Mathers, N., Fox, N. J., \& Hunn, A. (2000). Using Interviews in a Research Project. In Research Approaches in Primary Care (pp. 113-134). Radcliffe Medical Press.

Merdana, Seken, \& Putra, A. J. (2013). An Analysis of Speech Acts Produced by Elementary School Teachers and Students to Facilitate Teaching and Learning at SDN 10 Pringgasela East Lombok. eJournal Program Pascasarjana Universitas Pendidikan Ganesha .

Searle, J. R. (1969). Speech Acts. Cambridge: Cambridge University Press.

Summedi, S. H., \& Rovino, D. (2020). Speech Act Analysis of English Teacher Talk at SMP Negeri 1 Rangkasbitung. Journal of
English Language and Culture, 121-131.

Swandewi, I. A., Ramendra, D. P., \& Juniarta, P. A. (2018). An Analysis of Speech Acts used by English Teachers in Classroom Teaching and Learning Process at SMA Negeri 2 Banjar. Jurnal Pendidikan Bahasa Inggris Undiksha , 1-12.

Swastiana, I. N., Putra, A. J., \& Suarnajaya, I. W. (2020). An Analysis of Speech Acts Used by the Seventh-Grade Teacher of SMPN 2 Bangli in EFL Classroom. Journal of Educational Research and Evaluation , 49-58.

Yule, G. (1996). Pragmatics. London: Oxford University Press. 